OPEN ACCESS

Edited by:

Zhonglin Chai,

Monash University, Australia

Reviewed by:

Leslie Stuart Gewin,

Vanderbilt University, United States

Jay JHA,

Monash University, Australia

${ }^{*}$ Correspondence:

Fang Liu

liufangfh@163.com

Specialty section:

This article was submitted to

Molecular Medicine,

a section of the journal

Frontiers in Cell and Developmental

Biology

Received: 17 November 2019 Accepted: 05 March 2020

Published: 24 March 2020

Citation:

Zhao L, Zou Y and Liu F (2020) Transforming Growth Factor-Beta1 in Diabetic Kidney Disease. Front. Cell Dev. Biol. 8:187.

doi: 10.3389/fcell.2020.00187

\section{Transforming Growth Factor-Beta1 in Diabetic Kidney Disease}

\author{
Lijun Zhao, Yutong Zou and Fang Liu* \\ Division of Nephrology, West China Hospital, Sichuan University, Chengdu, China
}

Diabetic kidney disease (DKD) is the leading cause of end-stage renal disease (ESRD) worldwide. Renin-angiotensin-aldosterone system (RAAS) inhibitors and sodiumglucose co-transporter 2 (SGLT2) inhibitors have shown efficacy in reducing the risk of ESRD. However, patients vary in their response to RAAS blockades, and the pharmacodynamic responses to SGLT2 inhibitors decline with increasing severity of renal impairment. Thus, effective therapy for DKD is yet unmet. Transforming growth factor- $\beta 1$ (TGF- $\beta 1$ ), expressed by nearly all kidney cell types and infiltrating leukocytes and macrophages, is a pleiotropic cytokine involved in angiogenesis, immunomodulation, and extracellular matrix (ECM) formation. An overactive TGF- $\beta 1$ signaling pathway has been implicated as a critical profibrotic factor in the progression of chronic kidney disease in human DKD. In animal studies, TGF- $\beta 1$ neutralizing antibodies and TGF- $\beta 1$ signaling inhibitors were effective in ameliorating renal fibrosis in DKD. Conversely, a clinical study of TGF- $\beta 1$ neutralizing antibodies failed to demonstrate renal efficacy in DKD. However, overexpression of latent TGF- $\beta 1$ led to anti-inflammatory and anti-fibrosis effects in non-DKD. This evidence implied that complete blocking of TGF- $\beta 1$ signaling abolished its multiple physiological functions, which are highly associated with undesirable adverse events. Ideal strategies for DKD therapy would be either specific and selective inhibition of the profibrotic-related TGF- $\beta 1$ pathway or blocking conversion of latent TGF- $\beta 1$ to active TGF- $\beta 1$.

Keywords: diabetic kidney disease, transforming growth factor- $\beta 1$, fibrosis, inflammation, Smad signaling

\section{INTRODUCTION}

Diabetic kidney disease (DKD), the most common cause of end-stage renal disease (ESRD) worldwide, accounts for about $40 \%$ of new cases of ESRD each year in the United States and China (Zhang et al., 2016; Alicic et al., 2017). With the increasing incidence of diabetes, there is a heightened need for therapy to delay progression of DKD. Existing therapies have had limited success. Renin-angiotensin-aldosterone system (RAAS) inhibitors, such as losartan and irbesartan, have been effective in reducing the risk of ESRD for patients with DKD (Brenner et al., 2001; Lewis et al., 2001; Parving et al., 2001). However, patients exhibited great variation in their responses to RAAS blockades. In the past two decades, there has been a decline in the rate of acute myocardial infarction and death from hyperglycemic crisis, but no change has occurred in the rate of ESRD (Gregg et al., 2014). Although sodium-glucose co-transporter 2 (SGLT2) inhibitors have conferred cardiovascular and renal protection (Perkovic et al., 2019), effective therapy for DKD is still unavailable. An epidemiological study revealed that the 5-year mortality rate of DKD was 
approximately $40 \%$, as high as many cancers (Abdel Aziz et al., 2017). Transforming growth factor- $\beta 1$ (TGF- $\beta 1$ ) signaling contributes to DKD progression, and inhibiting TGF- $\beta 1$ signaling has shown potential renoprotective properties in animal and human studies. In this mini-review, we discuss the pleiotropic and the potential therapeutic effects of TGF- $\beta 1$ in DKD.

\section{TGF- $\beta 1$ AND TGF- $\beta 1$ SIGNALING PATHWAY}

TGF- $\beta$ s exist as five isoforms, but only TGF- $\beta 1$, TGF- $\beta 2$, and TGF- $\beta 3$ are present in mammals; the three isoforms elicit similar responses in vitro. TGF- $\beta 1$, the most abundant isoform, is synthesized by all types of resident renal cells and infiltrating inflammatory cells (Aihara et al., 2010). TGF- $\beta 1$ is secreted into the extracellular matrix (ECM) in an inactive complex (latent TGF- $\beta 1$ ) with TGF- $\beta$-latency-associated peptide (LAP) and latent TGF- $\beta$ binding proteins (LTBP) (Munger et al., 1997). The activation of latent TGF- $\beta 1$ is mediated by proteolytic cleavage in the presence of the serine protease plasmin, reactive oxygen species (ROS), thrombospondin-1 (TSP-1), or integrins (Khalil, 1999; Kim et al., 2018). Integrins bind to the arginine-glycineaspartic acid sequence in LAP. This binding appears to change the conformation of the latent TGF- $\beta 1$ complex by tractional force (Munger et al., 1999). This conformational change presents the latent TGF- $\beta 1$ complex to transmembrane metalloproteinases, such as membrane-type-1-matrix metalloproteinase (MT-1MMP), which cleave the latent TGF- $\beta 1$ complex and release active TGF- $\beta 1$ (Mu et al., 2002; Sheppard, 2004; Araya et al., 2006; Wipff and Hinz, 2008). Active TGF- $\beta 1$ interacts with its receptors to activate Smad-dependent and Smad-independent downstream signaling (Lan, 2011; Sutariya et al., 2016).

\section{Smad-Dependent Signaling Pathway}

Active TGF- $\beta 1$ binds to a Type II membrane receptor, TGF- $\beta$ Type II receptor (T $\beta$ RII). This binding results in the phosphorylation and recruitment of the TGF- $\beta$ Type I receptor (T $\beta R I)$. The activated complex of TGF- $\beta 1-T \beta R I-T \beta R I I$ phosphorylates Smad 2 and -3 . Then, the phosphorylated Smad2 and -3 bind to Smad4 to form the Smad complex (Lan, 2011). This Smad complex translocates into the nucleus and binds to Smad-binding elements (SBEs) or Smads-containing complexes (Nakao et al., 1997b; Meng et al., 2013), in turn, regulating transcription of genes encoding, e.g., collagen, fibronectin, $\alpha$-smooth muscle actin (Chakravarthy et al., 2018), and Smad7 (Yan et al., 2009).

Smad proteins are classified into three subgroups. Smad 2 and -3 comprise the receptor-regulated Smads (R-Smads) for TGF$\beta 1$ signaling, and Smad1, -5 , and -8 for bone morphogenetic protein (BMP) signaling. Smad2 and -3 are key downstream mediators of TGF- $\beta 1$, and they are highly activated in animal renal tissues in DKD (Isono et al., 2002; Høj Thomsen et al., 2017). Smad2 and -3 may have distinct functions in renal fibrosis. Either a Smad3 knockout or a Smad3-specific inhibitor delayed de-differentiation of proximal tubular cells and alleviated renal fibrosis in a streptozotocin-induced model of diabetes (Fujimoto et al., 2003; Li et al., 2010). These findings suggested that TGF- $\beta 1 / \mathrm{Smad} 3$ signaling has critical activities in renal fibrosis. Conversely, unlike Smad3, the function of Smad2 in DKD is unclear. Overexpression of Smad 2 attenuated TGF- $\beta 1$ induced phosphorylated Smad3 and collagen expression, whereas deletion of Smad2 promoted renal fibrosis via substantially enhanced Smad3 signaling (Meng et al., 2010; Loeffler et al., 2018). Although Smad2 interacts with Smad3 physically, Smad2 and -3 may compete for phosphorylation in response to TGF- $\beta 1$ stimulation. Thus, Smad 2 may competitively inhibit phosphorylation of Smad3 in response to TGF- $\beta 1$ (Meng et al., 2010). Besides TGF- $\beta 1$ signaling, Smad 2 nuclear translocation and phosphorylation can also be mediated by advanced glycation end-products in DKD (Li et al., 2004). Thus, the activity of Smad2 is complicated in DKD.

The second Smad subgroup is the common-partner Smad (co-Smad), Smad4, which forms a heterotrimeric complex with phosphorylated R-Smads. The Smad4-containing complex translocates into the nucleus and regulates expression of the genes indicated earlier. Furthermore, Smad4 is implicated in suppressing nuclear factor- $\kappa \mathrm{B}(\mathrm{NF}-\kappa \mathrm{B})$-driven inflammation by inducing Smad7 expression (Ka et al., 2012).

The third Smad subgroup is the inhibitory Smads (I-Smads). Members of this Smad family have a conserved carboxy-terminal $\mathrm{MH} 2$ domain. I-Smads inhibit TGF- $\beta 1$ family signaling via interaction with type I receptors, and I-Smads compete with R-Smads for receptor activation (Miyazawa and Miyazono, 2017). Smad7, one of the most investigated I-Smad in DKD, can cause degradation of T $\beta$ RI and Smads activity in a negative feedback process. Smad7 inhibits Smad2/3 during renal fibrosis. In chronic kidney disease, TGF- $\beta 1$ signaling upregulated the Smurfs and caused ubiquitin-dependent degradation of Smad7, which led to a decrease in Smad7 protein level (Kavsak et al., 2000; Ebisawa et al., 2001; Fukasawa et al., 2004; Liu et al., 2008). Smad7 knockout mice progressed to more severe interstitial fibrosis and enhanced inflammation (Cheng et al., 2013; Chung et al., 2013), and overexpression of Smad7 in kidney was effective in reducing collagen matrix expression and in alleviating inflammatory infiltration in DKD (Ka et al., 2012). These findings revealed anti-fibrotic and anti-inflammatory functions of Smad7 in DKD.

\section{Smad-Independent Signaling Pathway}

In addition to Smad-mediated transcription, TGF- $\beta 1$ directly activates other signal transduction pathways in the pathophysiology of kidney disease. These other pathways include the mitogen-activated protein kinases (MAPK) pathway (Meng, 2019), growth and survival kinases phosphatidylinositol-3-kinase (PI3K)/Akt (Lu et al., 2019), small GTP-binding proteins such as Ras, RhoA, Rac1, and Cdc42, the Notch signaling pathway (Atfi et al., 1997; Sweetwyne et al., 2015), Integrin-linked kinase (ILK), and the Wnt/ $\beta$-catenin pathway (Xu et al., 2017; Zhang and Huang, 2018). These non-canonical, non-Smad pathways can indirectly participate in de-differentiation of proximal tubular cells (Lu et al., 2019), apoptosis (Matoba et al., 2017), and matrix formation (Meng, 2019), thereby mediating signaling responses 
either as stand-alone pathways or as pathways that converge onto Smads to control Smad activities.

\section{TGF- $\beta 1$ PROMOTES RENAL FIBROSIS IN DKD}

Diabetic kidney disease pathology is characterized by thickening of the glomerular basement membrane, mesangial expansion, segmental glomerulosclerosis or global glomerulosclerosis, tubulointerstitial fibrosis, and afferent and efferent arteriole hyalinosis (Najafian et al., 2015). The TGF- $\beta 1$ signaling pathway is activated in $\mathrm{DKD}$, and the inhibition of TGF- $\beta 1$ attenuates fibrosis in animal models of diabetes (Meng, 2019). Pathogenic stimuli in DKD activate TGF- $\beta 1$ signaling. Angiotensin-II, which was elevated in mesangial cells and glomerular endothelial cells, has been implicated in activating TGF- $\beta 1$ by generation of ROS from nicotinamide adenine dinucleotide phosphate oxidases (Lee, 2011; Morales et al., 2012) or by activating protein kinase C- and p38 MAPK-dependent pathways (Weigert et al., 2002). Hyperglycemia, mechanical stretch, and advanced glycation end products were found to upregulate TGF- $\beta 1$ in DKD (Gruden et al., 2000; Chuang et al., 2015). TSP-1, a prototypic matricellular ECM protein, was heavily deposited in glomeruli of patients with DKD (Hohenstein et al., 2008). TSP-1 binds to the latent TGF- $\beta 1$ complex, and, by a non-proteolytic mechanism, converts latent TGF- $\beta 1$ to the active form, which leads to upregulation of TGF$\beta 1$ signaling (Murphy-Ullrich and Suto, 2018). Direct evidence for the importance of TSP-1 in regulating TGF- $\beta$ signaling in $\mathrm{DKD}$ comes from two different models of type 1 diabetes. Streptozotocin-treated TSP-1 knockout mice showed decreased glomerular TGF- $\beta$ signaling as measured by phosphorylated Smad2, and attenuated glomerulosclerosis (Daniel et al., 2007). In another type 1 diabetic animal model, uninephrectomized Akita mice treated with TSP-1 blocking peptide LSKL were protected from tubulointerstitial fibrosis and had reduced phosphorylation of Smad2 and -3 (Lu et al., 2011).

Mechanisms of TGF- $\beta 1$ regulated fibrosis in DKD are multifactorial and involve (1) overexpression of ECM, (2) decreased degradation of ECM, (3) enhanced cross-linking between collagen and elastin fibers, and (4) overactivation of proximal tubular and endothelial cell de-differentiation. Both canonical TGF- $\beta 1 /$ Smads-dependent signaling pathways and alternative signaling by TGF- $\beta 1$ are involved in stimulating collagen expression and accumulation. Neutralizing all three mammalian TGF- $\beta$ isoforms $(-\beta 1,-\beta 2$, and $-\beta 3)$ with antibodies reduced ECM gene (fibronectin and type IV collagen) expression and attenuated renal fibrosis in mice with type 1 or type 2 diabetes (Sharma et al., 1996; Ziyadeh et al., 2000). Thus, TGF- $\beta 1$ has a critical signaling function in ECM accumulation in DKD.

TGF- $\beta 1$ expression greatly inhibited ECM degradation by promoting the synthesis of plasminogen activator inhibitor-1 (PAI-1) which resulted in renal fibrosis (Shihab et al., 1997). The abundance of matrix metalloproteinase-9 (MMP-9), an ECM-degradation MMP, was decreased in transgenic mice that overexpressed TGF- $\beta 1$ (Zechel et al., 2002; Ueberham et al., 2003). In addition, TGF- $\beta 1$ augmented the expression of tissue inhibitor of metalloproteinases-1 (Ueberham et al., 2003; Abdel Aziz et al., 2017), which inhibited the ECM-degrading MMPs.

TGF- $\beta 1$ promotes formation of the cross-linking between collagen and elastin fibers by upregulating lysyl oxidase (Boak et al., 1994; Di Donato et al., 1997). In vitro, TGF- $\beta 1$ significantly increased ( $\sim 5$ times) lysyl oxidase expression in tubular epithelial cells (Di Donato et al., 1997). In addition, TGF$\beta 1$ stimulated expression of procollagen lysyl hydroxylase 2 , an enzyme that hydroxylates lysyl residues of collagen telopeptides and stabilizes collagen cross-linking (Gjaltema et al., 2015). Crosslinking increases ECM resistance to degradation by MMPs (El Hajj et al., 2018).

De-differentiation of the proximal tubular cells and endothelial cells contributes to renal fibrosis in diabetic mice. Extensive studies confirmed that TGF- $\beta 1$ contributes to renal fibrosis by stimulating proximal tubular de-differentiation (Zeisberg et al., 2003) and endothelial de-differentiation (Li et al., 2009; Pardali et al., 2017). Hypoxia-inducible factor $1 \alpha$ (HIF- $1 \alpha)$ accumulated in DKD and HIF- $1 \alpha$ enhanced dedifferentiation of murine proximal tubular epithelial cells in vitro (Higgins et al., 2007). Conditional HIF-1 $\alpha$ ablation decreased interstitial collagen deposition and inhibited the development of tubulointerstitial fibrosis (Higgins et al., 2007). Although TGF$\beta 1$ stimulation increased HIF- $1 \alpha$ expression, blocking TGF- $\beta 1$ signaling inhibited HIF- $1 \alpha$ activity, and, conversely, blocking HIF- $1 \alpha$ activity decreased TGF- $\beta 1$ signaling (Basu et al., 2011). These studies suggested cross-talk between TGF- $\beta 1$ and HIF- $1 \alpha$ signaling in regulating proximal tubular de-differentiation (Basu et al., 2011). As to endothelial de-differentiation, in animal models of folic acid nephropathy or unilateral ureteral obstruction, curtailed TGF- $\beta$ signaling in the endothelium by endothelium-specific heterozygous T $\beta$ RII knockout reduced endothelial de-differentiation and led to less tubulointerstitial fibrosis (Xavier et al., 2015). The mechanism by which TGF- $\beta 1$ regulates endothelial de-differentiation is unknown. TGF- $\beta 1$ stimulated endothelial de-differentiation in mouse endothelial cells by activating Snail expression (Kokudo et al., 2008).

In summary, the active TGF- $\beta 1$ system promotes renal fibrosis, and it is involved in elevating collagen synthesis, suppressing ECM degradation, promoting collagen crosslinking, and fostering proximal tubular or endothelial cell dedifferentiation (Figure 1).

\section{DIVERSE INFLAMMATORY FUNCTIONS OF TGF- $\beta 1$ IN DKD}

TGF- $\beta 1$ is a critical factor in the pathophysiological progression of DKD, having both pro- and anti-inflammatory properties (Sureshbabu et al., 2016).

TGF- $\beta 1$ control of innate immune cells can have severe pathological consequences. Leukocytes and fibroblasts are recruited by the activation of resident kidney immune cells in DKD. This recruitment stimulates the expression of proinflammatory and chemotactic cytokines, which further drives the infiltration of monocytes and macrophages (Lv et al., 2018). TGF- $\beta 1$ recruited macrophages and dendritic cells by stimulating 


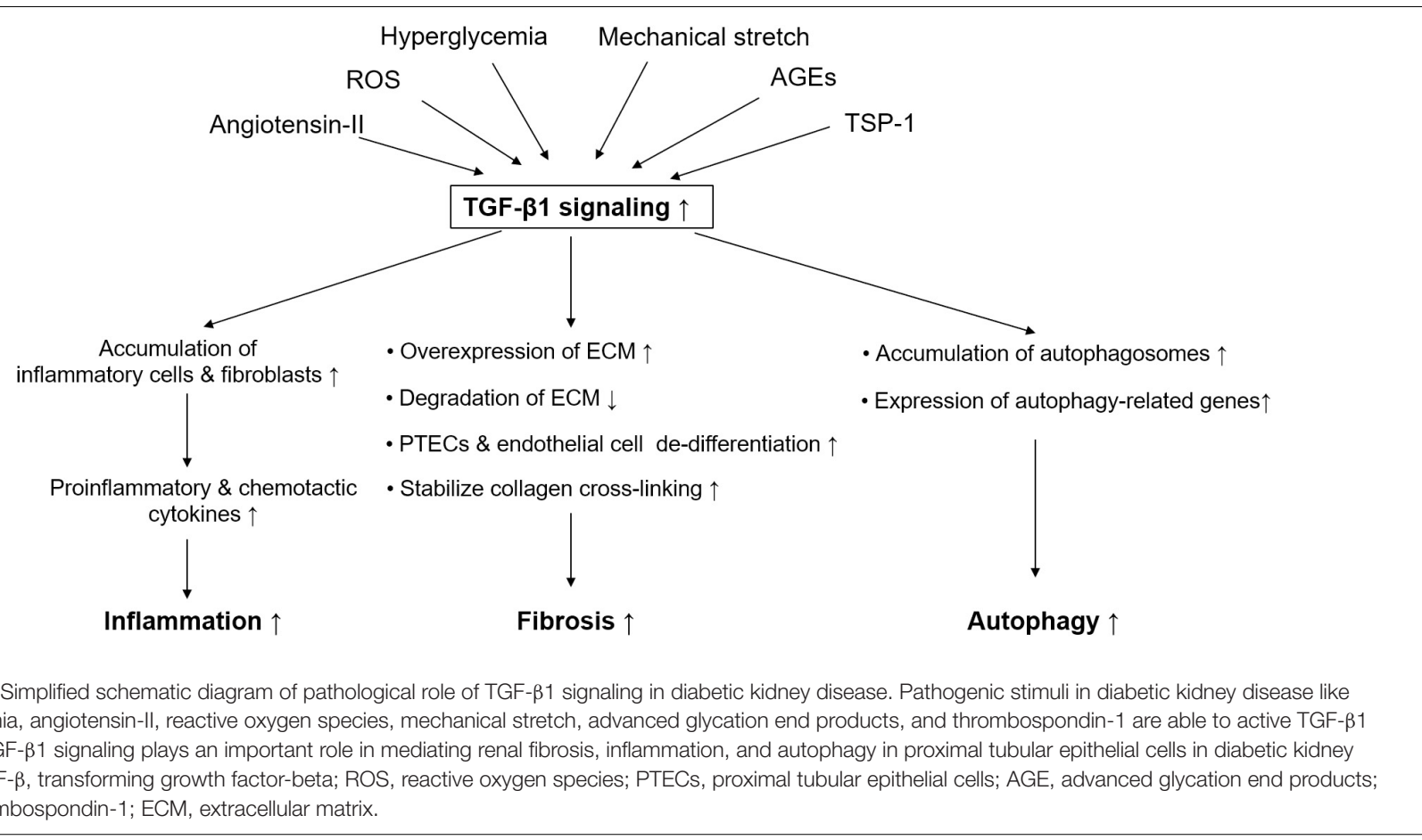

the production of chemokines, including tumor necrosis factoralpha (TNF- $\alpha$ ), monocyte chemoattractant protein-1 (MCP-1), and inducible nitric oxide synthase. Furthermore, the secreted chemokines induced TGF- $\beta 1$ expression in a positive feedback loop (Cheng et al., 2005), which sustained the high levels of TGF$\beta 1$ in the microenvironment. TGF- $\beta 1$ induced the expression and release of other proinflammatory cytokines such as interleukin-8 (IL-8) and MCP-1 (Qi et al., 2006) in proximal tubular cells. In addition, TGF- $\beta 1$ drove the differentiation of T helper 17 cells, which were activated in various proinflammatory conditions. In the presence of IL- 6 , TGF- $\beta 1$ promoted the differentiation of naive $\mathrm{T}$ lymphocytes into proinflammatory $\mathrm{T}$ helper cells that produced IL-17 and augmented autoimmune conditions, which were enhanced by IL-1 $\beta$ and TNF- $\alpha$ (Korn et al., 2009; Sanjabi et al., 2009). In this way, TGF- $\beta 1$ propagates and amplifies the proinflammatory and profibrotic processes that contribute to renal insufficiency in DKD (Figure 1).

Nevertheless, TGF- $\beta 1$ also possesses anti-inflammatory properties, which was suggested by the findings that targeted deletion of the TGF- $\beta 1$ gene resulted in profound multifocal inflammatory disease in mice (Shull et al., 1992). Additionally, TGF- $\beta 1$ knockout mice developed severe inflammatory responses that were evidenced by massive lymphocytes, macrophages, immunoblasts, and plasma cell infiltration in many organs (Kulkarni et al., 1993). Tubular epithelial cell-specific TRRII knockout mice showed massive leukocytes or macrophages infiltration, increased proinflammatory cytokine release, and enhanced renal inflammation (Meng et al., 2012). Direct evidence for the importance of TGF- $\beta 1$ in anti-inflammation comes from two studies. First, Ma et al. (2004) used animal studies to investigate the effect of different doses of TGF- $\beta$ antibodies on glomerulosclerosis. Only low dose TGF- $\beta$ antibody decreased macrophage infiltration, and reduced sclerosis, indicating that the amount of TGF- $\beta$ may influence the inflammatory process. Second, regulatory $\mathrm{T}$ cells appeared to ameliorate $\mathrm{DKD}$, and nude mice, which lacked all T-cell subtypes, had more severe DKD (Lim et al., 2010; Eller et al., 2011). In the presence of IL-2, TGF- $\beta 1$ converted naive T cells into Foxp 3 + regulatory T cells and inhibited the progression of DKD (Davidson et al., 2007; Kanamori et al., 2016).

Thus, the effects of TGF- $\beta 1$ activation in renal inflammation may be protective or harmful depending on concentration or the presence of IL-6. However, the underlying mechanism by which TGF- $\beta 1$ exerts its anti-inflammatory properties in DKD requires further investigation.

\section{OTHER ACTIVITIES OF TGF- $\beta 1$ IN DKD}

Recent studies illustrated that TGF- $\beta 1$ promoted autophagy (Ding et al., 2010; Koesters et al., 2010). Autophagy, a system for removing protein aggregates and damaged organelles to maintain cellular homeostasis, is impaired in glomeruli and tubules in DKD (Yang et al., 2018). However, persistent activation of autophagy in kidney tubular epithelial cells induced tubular degeneration and promoted renal fibrosis (Livingston et al., 2016). Overexpression of TGF- $\beta 1$ in renal tubules induced the accumulation of autophagosomes and stimulated expression of autophagy-related genes (Koesters et al., 2010; Xu et al., 2012). In proximal tubular cells, TGF- $\beta 1$ promoted autophagy by generation of ROS, which contributed to the proapoptotic effect of TGF- $\beta 1$ (Xu et al., 2012). Koesters et al. (2010) proposed TGF- $\beta 1$-driven autophagy as a novel mechanism of tubular degeneration that led to renal interstitial fibrosis. On the 
contrary, TGF- $\beta 1$ induced autophagy had positive effects. In a study by Ding et al. (2010), TGF- $\beta 1$ induced autophagy in mesangial cells, and autophagy enhanced cell survival by preventing mesangial cells from undergoing apoptosis. Whether TGF- $\beta 1$ driven autophagy has protective or deleterious effects on kidney depending upon the amount. In the study by Koesters et al., TGF- $\beta 1$ level was higher than its level in pathological disease states, which triggered violent autophagy and promoted kidney injury. Thus, we need further clarification of the functions of TGF- $\beta 1$ signaling-induced autophagy in the pathogenesis of DKD.
TGF- $\beta 1$ also suppresses reabsorption of glucose by proximal epithelial cells. A dose-dependent increase in TGF- $\beta 1$ expression by genetic manipulation increased urinary output of glucose in Akita mice, whereas genetic insufficiency of TGF- $\beta 1$ decreased glucose output (Hathaway et al., 2015). Moreover, SGLT2 was directly regulated by TGF- $\beta 1$ via Smad3 (Panchapakesan et al., 2013) and TGF- $\beta 1$ showed decreased expression of SGLT1 and SGLT2 (Lee and Han, 2010). Thus, these results support the notion that TGF- $\beta 1$ suppresses urinary glucose reabsorption in proximal tubular epithelial cells (Figure 1).

TABLE 1 | Pre-clinical and clinical studies aimed to TGF- $\beta$ signaling in diabetic kidney disease.

\begin{tabular}{|c|c|c|c|c|}
\hline Authors & Target & Method & Subject & Major findings \\
\hline \multicolumn{5}{|l|}{ Preclinical studies } \\
\hline Sharma et al., 1996 & TGF- $\beta 1$, TGF- $\beta 2$, TGF- $\beta 3$ & $\begin{array}{l}\text { Neutralizing monoclonal } \\
\text { antibody }\end{array}$ & $\begin{array}{l}\text { Streptozotocin-induced } \\
\text { diabetic mice }\end{array}$ & Attenuated renal fibrosis \\
\hline Ziyadeh et al., 2000 & TGF- $\beta 1$, TGF- $\beta 2$, TGF- $\beta 3$ & $\begin{array}{l}\text { Neutralizing monoclonal } \\
\text { antibody }\end{array}$ & $d b / d b$ mice & $\begin{array}{l}\text { Decreased glomerular mesangial matrix } \\
\text { expansion and attenuated renal fibrosis }\end{array}$ \\
\hline Chen et al., 2003 & TGF- $\beta 1$, TGF- $\beta 2$, TGF- $\beta 3$ & $\begin{array}{l}\text { Neutralizing monoclonal } \\
\text { antibody }\end{array}$ & $d b / d b$ mice & $\begin{array}{l}\text { Reversed the glomerular basement } \\
\text { membrane thickening and mesangial } \\
\text { matrix expansion, attenuated renal } \\
\text { fibrosis }\end{array}$ \\
\hline Benigni et al., 2006 & TGF- $\beta 1$, TGF- $\beta 2$, TGF- $\beta 3$ & $\begin{array}{l}\text { Neutralizing monoclonal } \\
\text { antibody }\end{array}$ & $\begin{array}{l}\text { Streptozotocin-induced } \\
\text { diabetic mice }\end{array}$ & $\begin{array}{l}\text { Alleviated sclerotic glomerulosclerosis } \\
\text { and attenuated renal fibrosis }\end{array}$ \\
\hline Petersen et al., 2008 & $\begin{array}{l}\text { TGF- } \beta \text { type I and type } \| \\
\text { receptor kinase activity }\end{array}$ & $\begin{array}{l}\text { GW788388, } \\
\text { pharmacological inhibitor }\end{array}$ & $d b / d b$ mice & $\begin{array}{l}\text { Decreased epithelial-mesenchymal } \\
\text { transitions and attenuated renal fibrosis }\end{array}$ \\
\hline $\begin{array}{l}\text { RamachandraRao } \\
\text { et al., } 2009\end{array}$ & $\begin{array}{l}\text { TGF- } \beta 1 \text { promoter activity; other } \\
\text { pathways besides TGF- } \beta \\
\text { (suppressing production of } \\
\text { reactive oxygen species and } \\
\text { downregulating profibrotic } \\
\text { cytokine genes) }\end{array}$ & $\begin{array}{l}\text { Pirfenidone, a } \\
\text { pharmacological inhibitor }\end{array}$ & $d b / d b$ mice & $\begin{array}{l}\text { Ameliorated mesangial matrix } \\
\text { expansion and attenuated renal fibrosis }\end{array}$ \\
\hline Hathaway et al., 2015 & TGF- $\beta 1$ & Genetic overexpression & Akita mice & $\begin{array}{l}\text { Progressively exacerbated thicker } \\
\text { glomerular basement membranes and } \\
\text { severe podocyte effacement is } \\
\text { dose-dependent }\end{array}$ \\
\hline Fujimoto et al., 2003 & Smad3 & Genetic knockout & $\begin{array}{l}\text { Streptozotocin-induced } \\
\text { diabetic mice }\end{array}$ & $\begin{array}{l}\text { Alleviated glomerular basement } \\
\text { membrane thickness and attenuated } \\
\text { renal fibrosis }\end{array}$ \\
\hline Li et al., 2010 & Smad3 & $\begin{array}{l}\text { SIS3, pharmacological } \\
\text { inhibitor }\end{array}$ & $\begin{array}{l}\text { Streptozotocin-induced } \\
\text { diabetic mice }\end{array}$ & Attenuated renal fibrosis \\
\hline Ka et al., 2012 & Smad7 & $\begin{array}{l}\text { Ultrasound-mediated gene } \\
\text { transfer of inducible Smad7 } \\
\text { overexpression plasmids }\end{array}$ & $d b / d b$ mice & $\begin{array}{l}\text { Inhibited diabetic kidney injury including } \\
\text { fibrosis and inflammation }\end{array}$ \\
\hline Loeffler et al., 2018 & Smad2 & $\begin{array}{l}\text { Renal tubular, endothelial, } \\
\text { and interstitial cells-specific } \\
\text { knockout }\end{array}$ & $\begin{array}{l}\text { Streptozotocin-induced } \\
\text { diabetic mice }\end{array}$ & $\begin{array}{l}\text { Reduced epithelial-to-mesenchymal } \\
\text { transition and attenuated renal fibrosis }\end{array}$ \\
\hline \multicolumn{5}{|l|}{ Clinical studies } \\
\hline Sharma et al., 2011 & $\begin{array}{l}\text { TGF- } \beta 1 \text { promoter activity; other } \\
\text { pathways besides TGF- } \beta \\
\text { (suppressing production of } \\
\text { reactive oxygen species and } \\
\text { downregulating profibrotic } \\
\text { cytokine genes) }\end{array}$ & $\begin{array}{l}\text { Pirfenidone, a } \\
\text { pharmacological inhibitor }\end{array}$ & $\begin{array}{l}\text { Type } 1 \text { and type } 2 \\
\text { diabetic patients }\end{array}$ & $\begin{array}{l}\text { Increased estimated glomerular filtration } \\
\text { rate level }\end{array}$ \\
\hline Voelker et al., 2017 & TGF- $\beta 1$ & $\begin{array}{l}\text { Neutralizing monoclonal } \\
\text { antibody added to renin- } \\
\text { angiotensin-aldosterone } \\
\text { system inhibitor }\end{array}$ & $\begin{array}{l}\text { Type } 1 \text { and type } 2 \\
\text { diabetic patients }\end{array}$ & $\begin{array}{l}\text { Failed to slow the progression of } \\
\text { diabetic kidney disease }\end{array}$ \\
\hline
\end{tabular}

TGF- $\beta 1$, transforming growth factor- $\beta 1$. 


\section{TGF- $\beta 1$ SIGNALING AS A THERAPEUTIC STRATEGY FOR DKD}

Blockade of TGF- $\beta 1$ signaling as a therapeutic strategy has been achieved by gene technology and pharmacological drugs (Table 1). Inhibition of TGF- $\beta$ with a pan-neutralizing monoclonal antibody (1D11) against all three isoforms ameliorated renal fibrosis and alleviated kidney structural changes in the rodent models of type 1 and type 2 diabetes mellitus (Sharma et al., 1996; Ziyadeh et al., 2000; Chen et al., 2003; Benigni et al., 2006). Pirfenidone is a low molecular weight synthetic molecule that has antifibrotic properties in animal models; it suppresses production of ROS and downregulates genes encoding profibrotic cytokines, such as $\alpha$-SMA, collagen I, and collagen IV. Pirfenidone upregulates regulator of G-protein signaling 2 (Xie et al., 2016; Li et al., 2018; Pourgholamhossein et al., 2018). Moreover, RamachandraRao et al. (2009) found that pirfenidone decreased TGF- $\beta$ promoter activity, blocked TGF- $\beta 1$ production, and was effective in reducing mesangial matrix expansion and fibrosis in DKD. Switching TGF- $\beta 1$ expression from low to high by genetic manipulation exacerbated renal injury in Akita mice, a result that further supported the idea that blockade of TGF- $\beta 1$ was renoprotective for DKD (Hathaway et al., 2015).

The success of TGF- $\beta 1$ signaling inhibition in animal studies has promoted the strategy in clinical investigations with DKD (Sharma et al., 2011; Voelker et al., 2017). Pirfenidone significantly increased estimated glomerular filtration rates (eGFR) in a cohort of 77 diabetic patients with baseline eGFR of $20-75 \mathrm{ml} / \mathrm{min} / 1.73 \mathrm{~m}^{2}$ (Sharma et al., 2011). However, a placebocontrolled, phase II study that used a humanized TGF- $\beta 1$-specific neutralizing monoclonal antibody plus renin-angiotensin system blockades failed to slow the progression of DKD in diabetic patients who had eGFR of $20-60 \mathrm{ml} / \mathrm{min} / 1.73 \mathrm{~m}^{2}$ (Voelker et al., 2017). Lack of improvement in clinical trials may be explained by the fact that rodent models of diabetes do not recapitulate tubulointerstitial fibrosis to the same degree observed in human disease. Also, inhibiting TGF- $\beta 1$ fully and indiscriminately may not be wise because of its multiple physiological functions.

Nevertheless, targeting the conversion of latent to active TGF$\beta 1$ holds promise as a DKD therapeutic intervention. Animal studies revealed that overexpression of an active form of TGF$\beta 1$ in liver led to progressive kidney fibrosis in mice (Kopp et al., 1996), whereas overexpression of latent TGF- $\beta 1$ in the skin displayed anti-inflammatory and anti-fibrosis effects in obstructive and crescentic glomerulonephritis (Huang et al., $2008 \mathrm{a}, \mathrm{b})$. The distinct functions of active and latent TGF$\beta 1$ in renal fibrosis and inflammation suggest that a better therapeutic approach would be to block conversion of latent TGF- $\beta$ to active TGF- $\beta$. Wong et al. (2011) showed that inhibiting conversion of latent to active TGF- $\beta 1$ in human proximal tubular cells reduced matrix protein expression and inhibited fibrosis under hyperglycemia and hypoxia conditions. What is more, the $\alpha \mathrm{v}$-containing integrins with different $\beta$-subunits that interact with latent TGF- $\beta 1$ and activate TGF- $\beta 1$ have a critical function in kidney fibrosis. A pharmacologic inhibitor of $\alpha v \beta 1$ integrin prevented activation of the latent TGF- $\beta$ complex and ameliorated renal fibrosis in mice fed an adenine diet (Chang et al., 2017). The mechanisms of the distinct functions of latent versus active TGF- $\beta 1$ may be related to the prevention of Smad7 from Smurf-mediated ubiquitination and degradation in response to higher levels of latent TGF- $\beta 1$ (Lan, 2011). Smad7 inhibits TGF- $\beta$ signaling by promoting degradation of the TBRI and inhibiting Smad2/3/4 activity (Nakao et al., 1997a; Miyazawa and Miyazono, 2017). But in chronic kidney disease, active TGF- $\beta 1$ activates the Smurfs and arkadia-dependent ubiquitinproteasome pathways, which degrades Smad7 protein by a posttranscriptional modification mechanism (Kavsak et al., 2000; Ebisawa et al., 2001; Fukasawa et al., 2004).

\section{CONCLUSION}

On the basis of experimental and clinical studies, modulating TGF- $\beta 1$, instead of directly inhibiting TGF- $\beta 1$ ligands/receptors, may be a good antifibrosis tactic for DKD. TGF- $\beta 1$ promotes wound healing (Wang et al., 2014), tissue regeneration (Borges et al., 2013), anti-inflammation (Kulkarni et al., 1993), autophagy (Koesters et al., 2010), and urinary glucose regulation (Hathaway et al., 2015). Nonetheless, the dose regimen must be considered carefully because a large dose of TGF- $\beta$ blockade had severe toxicity and poor efficacy in animal experiments (Khanna et al., 2004; Ma et al., 2004). A pan-neutralizing monoclonal antibody could also lead to undesired effects such as tumor formation, even though animal studies have not exhibited such events during prolonged TGF- $\beta 1$ inhibition. What is more, developing molecules that suppress the activation of latent TGF$\beta 1$ would be a potential therapy. Given the central role of TGF- $\beta 1$ in the pathophysiology of DKD, the TGF- $\beta 1$ system is an attractive target to retard the progression of DKD, provided that the approach maintains an acceptable balance between renoprotective and harmful effects.

\section{AUTHOR CONTRIBUTIONS}

LZ and FL conceptualized this review and decided on the content. LZ, YZ, and FL wrote and revised the manuscript. All authors approved the final version of the manuscript.

\section{FUNDING}

This study was supported by the National Natural Science Foundation of China (Grant Nos. 81970626 and 81670662) and Key Research and Development Project of Sichuan Science Technology Department (Grant No. 19ZDYF1273).

\section{ACKNOWLEDGMENTS}

We thank AiMi Academic Services for English language editing and review services. 


\section{REFERENCES}

Abdel Aziz, M. A., Badary, D. M., and Hussein, M. R. A. (2017). Renal damage following Alloxan-induced diabetes is associated with generation of reactive oxygen species, alterations of p53, TGF-betal, and extracellular matrix metalloproteinases in rats. Cell Biol. Int. 41, 525-533. doi: 10.1002/cbin. 10752

Aihara, K., Ikeda, Y., Yagi, S., Akaike, M., and Matsumoto, T. (2010). Transforming growth factor-betal as a common target molecule for development of cardiovascular diseases, renal insufficiency and metabolic syndrome. Cardiol. Res. Pract. 2011:175381. doi: 10.4061/2011/175381

Alicic, R. Z., Rooney, M. T., and Tuttle, K. R. (2017). Diabetic kidney disease: challenges, progress, and possibilities. Clin. J. Am. Soc. Nephrol. 12, 2032-2045. doi: 10.2215/CJN.11491116

Araya, J., Cambier, S., Morris, A., Finkbeiner, W., and Nishimura, S. L. (2006). Integrin-mediated transforming growth factor-beta activation regulates homeostasis of the pulmonary epithelial-mesenchymal trophic unit. Am. J. Pathol. 169, 405-415. doi: 10.2353/ajpath.2006.060049

Atfi, A., Djelloul, S., Chastre, E., Davis, R., and Gespach, C. (1997). Evidence for a role of Rho-like GTPases and stress-activated protein kinase/c-Jun N-terminal kinase (SAPK/JNK) in transforming growth factor beta-mediated signaling. J. Biol. Chem. 272, 1429-1432. doi: 10.1074/jbc.272.3.1429

Basu, R. K., Hubchak, S., Hayashida, T., Runyan, C. E., Schumacker, P. T., and Schnaper, H. W. (2011). Interdependence of HIF-1alpha and TGF-beta/Smad3 signaling in normoxic and hypoxic renal epithelial cell collagen expression. Am. J. Physiol. Renal Physiol. 300, F898-F905. doi: 10.1152/ajprenal.00335. 2010

Benigni, A., Zoja, C., Campana, M., Corna, D., Sangalli, F., Rottoli, D., et al. (2006). Beneficial effect of TGFbeta antagonism in treating diabetic nephropathy depends on when treatment is started. Nephron Exp. Nephrol. 104, e158-e168. doi: $10.1159 / 000094967$

Boak, A. M., Roy, R., Berk, J., Taylor, L., Polgar, P., Goldstein, R. H., et al. (1994). Regulation of lysyl oxidase expression in lung fibroblasts by transforming growth factor-beta 1 and prostaglandin E2. Am. J. Respir. Cell Mol. Biol. 11, 751-755. doi: 10.1165/ajrcmb.11.6.7946403

Borges, F. T., Melo, S. A., Özdemir, B. C., Kato, N., Revuelta, I., Miller, C. A., et al. (2013). TGF- $\beta 1$-containing exosomes from injured epithelial cells activate fibroblasts to initiate tissue regenerative responses and fibrosis. J. Am. Soc. Nephrol. 24, 385-392. doi: 10.1681/asn.2012101031

Brenner, B. M., Cooper, M. E., de Zeeuw, D., Keane, W. F., Mitch, W. E., Parving, H. H., et al. (2001). Effects of losartan on renal and cardiovascular outcomes in patients with type 2 diabetes and nephropathy. N. Engl. J. Med. 345, 861-869. doi: 10.1056/NEJMoa011161

Chakravarthy, A., Khan, L., Bensler, N. P., Bose, P., and De Carvalho, D. D. (2018). TGF- $\beta$-associated extracellular matrix genes link cancer-associated fibroblasts to immune evasion and immunotherapy failure. Nat. Commun. 9:4692. doi: 10.1038/s41467-018-06654-8

Chang, Y., Lau, W. L., Jo, H., Tsujino, K., Gewin, L., Reed, N. I., et al. (2017). Pharmacologic blockade of v1 integrin ameliorates renal failure and fibrosis. J. Am. Soc. Nephrol. 28, 1998-2005. doi: 10.1681/ASN.201505 0585

Chen, S., Iglesias-de la Cruz, M. C., Jim, B., Hong, S. W., Isono, M., and Ziyadeh, F. N. (2003). Reversibility of established diabetic glomerulopathy by anti-TGFbeta antibodies in db/db mice. Biochem. Biophys. Res. Commun. 300, 16-22. doi: 10.1016/s0006-291x(02)02708-0

Cheng, J., Diaz Encarnacion, M. M., Warner, G. M., Gray, C. E., Nath, K. A., and Grande, J. P. (2005). TGF-betal stimulates monocyte chemoattractant protein-1 expression in mesangial cells through a phosphodiesterase isoenzyme 4-dependent process. Am. J. Physiol. Cell Physiol. 289, C959-C970. doi: 10.1152/ ajpcell.00153.2005

Cheng, Y., Cui, T., Fu, P., Liu, F., and Zhou, L. (2013). Dyslipidemia is associated with tunneled-cuffed catheter-related central venous thrombosis in hemodialysis patients: a retrospective, multicenter study. Artif. Organs 37, E155-E161. doi: 10.1111/aor.12086

Chuang, C.-T., Guh, J.-Y., Lu, C.-Y., Chen, H.-C., and Chuang, L.-Y. (2015). $\mathrm{S} 100 \mathrm{~B}$ is required for high glucose-induced pro-fibrotic gene expression and hypertrophy in mesangial cells. Int. J. Mol. Med. 35, 546-552. doi: 10.3892/ ijmm.2014.2024
Chung, A. C., Dong, Y., Yang, W., Zhong, X., Li, R., and Lan, H. Y. (2013). Smad7 suppresses renal fibrosis via altering expression of TGF- $\beta / S$ mad3-regulated microRNAs. Mol. Ther. 21, 388-398. doi: 10.1038/mt.2012.251

Daniel, C., Schaub, K., Amann, K., Lawler, J., and Hugo, C. (2007). Thrombospondin-1 is an endogenous activator of TGF-beta in experimental diabetic nephropathy in vivo. Diabetes 56, 2982-2989. doi: 10.2337/db070551

Davidson, T. S., DiPaolo, R. J., Andersson, J., and Shevach, E. M. (2007). Cutting Edge: IL-2 is essential for TGF-beta-mediated induction of Foxp3+ T regulatory cells. J. Immunol. 178, 4022-4026. doi: 10.4049/jimmunol.178.7.4022

Di Donato, A., Ghiggeri, G. M., Di Duca, M., Jivotenko, E., Acinni, R., Campolo, J., et al. (1997). Lysyl oxidase expression and collagen cross-linking during chronic adriamycin nephropathy. Nephron 76, 192-200. doi: 10.1159/000190168

Ding, Y., Kim, J. K., Kim, S. I., Na, H. J., Jun, S. Y., Lee, S. J., et al. (2010). TGF$\beta 1$ protects against mesangial cell apoptosis via induction of autophagy. J. Biol. Chem. 285, 37909-37919. doi: 10.1074/jbc.M109.093724

Ebisawa, T., Fukuchi, M., Murakami, G., Chiba, T., Tanaka, K., Imamura, T., et al. (2001). Smurf1 interacts with transforming growth factor-beta type I receptor through Smad7 and induces receptor degradation. J. Biol. Chem. 276, 12477-12480. doi: 10.1074/jbc.C100008200

El Hajj, E. C., El Hajj, M. C., Ninh, V. K., and Gardner, J. D. (2018). Inhibitor of lysyl oxidase improves cardiac function and the collagen/MMP profile in response to volume overload. Am. J. Physiol. Heart Circ. Physiol. 315, H463-H473. doi: 10.1152/ajpheart.00086.2018

Eller, K., Kirsch, A., Wolf, A. M., Sopper, S., Tagwerker, A., Stanzl, U., et al. (2011). Potential role of regulatory $\mathrm{T}$ cells in reversing obesity-linked insulin resistance and diabetic nephropathy. Diabetes 60, 2954-2962. doi: 10.2337/db11-0358

Fujimoto, M., Maezawa, Y., Yokote, K., Joh, K., Kobayashi, K., Kawamura, H., et al. (2003). Mice lacking Smad3 are protected against streptozotocin-induced diabetic glomerulopathy. Biochem. Biophys. Res. Commun. 305, 1002-1007. doi: $10.1016 / \mathrm{s} 0006-291 \mathrm{x}(03) 00885-4$

Fukasawa, H., Yamamoto, T., Togawa, A., Ohashi, N., Fujigaki, Y., Oda, T., et al. (2004). Down-regulation of Smad7 expression by ubiquitin-dependent degradation contributes to renal fibrosis in obstructive nephropathy in mice. Proc. Natl. Acad. Sci. U.S.A. 101, 8687-8692. doi: 10.1073/pnas.0400035101

Gjaltema, R. A., de Rond, S., Rots, M. G., and Bank, R. A. (2015). Procollagen Lysyl Hydroxylase 2 expression is regulated by an alternative downstream transforming growth factor $\beta-1$ activation mechanism. J. Biol. Chem. 290, 28465-28476. doi: 10.1074/jbc.M114.634311

Gregg, E. W., Li, Y., Wang, J., Burrows, N. R., Ali, M. K., Rolka, D., et al. (2014). Changes in diabetes-related complications in the United States, 1990-2010. N. Engl. J. Med. 370, 1514-1523. doi: 10.1056/NEJMoa1310799

Gruden, G., Zonca, S., Hayward, A., Thomas, S., Maestrini, S., Gnudi, L., et al. (2000). Mechanical stretch-induced fibronectin and transforming growth factor-betal production in human mesangial cells is p38 mitogen-activated protein kinase-dependent. Diabetes 49, 655-661. doi: 10.2337/diabetes.49. 4.655

Hathaway, C. K., Gasim, A. M., Grant, R., Chang, A. S., Kim, H. S., Madden, V. J., et al. (2015). Low TGF $\beta 1$ expression prevents and high expression exacerbates diabetic nephropathy in mice. Proc. Natl. Acad. Sci. U.S.A. 112, 5815-5820. doi: 10.1073/pnas.1504777112

Higgins, D. F., Kimura, K., Bernhardt, W. M., Shrimanker, N., Akai, Y., Hohenstein, B., et al. (2007). Hypoxia promotes fibrogenesis in vivo via HIF1 stimulation of epithelial-to-mesenchymal transition. J. Clin. Invest. 117, 3810-3820. doi: 10.1172/jci30487

Hohenstein, B., Daniel, C., Hausknecht, B., Boehmer, K., Riess, R., Amann, K. U., et al. (2008). Correlation of enhanced thrombospondin-1 expression, TGFbeta signalling and proteinuria in human type-2 diabetic nephropathy. Nephrol. Dial. Transplant 23, 3880-3887. doi: 10.1093/ndt/gfn399

Høj Thomsen, L., Fog-Tonnesen, M., Nielsen Fink, L., Norlin, J., de Vinuesa, A. G., Krarup Hansen, T., et al. (2017). Smad2 phosphorylation in diabetic kidney tubule epithelial cells is associated with modulation of several transforming growth factor- $\beta$ family members. Nephron 135, 291-306. doi: 10.1159/ 000453337

Huang, X. R., Chung, A. C., Wang, X. J., Lai, K. N., and Lan, H. Y. (2008a). Mice overexpressing latent TGF-betal are protected against renal fibrosis in obstructive kidney disease. Am. J. Physiol. Renal Physiol. 295, F118-F127. doi: 10.1152/ajprenal.00021.2008 
Huang, X. R., Chung, A. C., Zhou, L., Wang, X. J., and Lan, H. Y. (2008b). Latent TGF-betal protects against crescentic glomerulonephritis. J. Am. Soc. Nephrol. 19, 233-242. doi: 10.1681/asn.2007040484

Isono, M., Chen, S., Hong, S. W., Iglesias-de la Cruz, M. C., and Ziyadeh, F. N. (2002). Smad pathway is activated in the diabetic mouse kidney and Smad3 mediates TGF-beta-induced fibronectin in mesangial cells. Biochem. Biophys. Res. Commun. 296, 1356-1365. doi: 10.1016/s0006-291x(02)02084-3

Ka, S. M., Yeh, Y. C., Huang, X. R., Chao, T. K., Hung, Y. J., Yu, C. P., et al. (2012). Kidney-targeting Smad7 gene transfer inhibits renal TGF- $\beta$ /MAD homologue (SMAD) and nuclear factor $\kappa \mathrm{B}(\mathrm{NF}-\kappa \mathrm{B})$ signalling pathways, and improves diabetic nephropathy in mice. Diabetologia 55, 509-519. doi: 10.1007/s00125011-2364-5

Kanamori, M., Nakatsukasa, H., Okada, M., Lu, Q., and Yoshimura, A. (2016). Induced regulatory $\mathrm{T}$ cells: their development, stability, and applications. Trends Immunol. 37, 803-811. doi: 10.1016/j.it.2016.08.012

Kavsak, P., Rasmussen, R. K., Causing, C. G., Bonni, S., Zhu, H., Thomsen, G. H., et al. (2000). Smad7 binds to Smurf2 to form an E3 ubiquitin ligase that targets the TGF beta receptor for degradation. Mol. Cell 6, 1365-1375. doi: 10.1016/ s1097-2765(00)00134-9

Khalil, N. (1999). TGF-beta: from latent to active. Microbes Infect 1, 1255-1263. doi: 10.1016/s1286-4579(99)00259-2

Khanna, A. K., Plummer, M. S., Hilton, G., Pieper, G. M., and Ledbetter, S. (2004). Anti-transforming growth factor antibody at low but not high doses limits cyclosporine-mediated nephrotoxicity without altering rat cardiac allograft survival: potential of therapeutic applications. Circulation 110, 3822-3829. doi: 10.1161/01.Cir.0000150400.15354.7d

Kim, K. K., Sheppard, D., and Chapman, H. A. (2018). TGF- $\beta 1$ signaling and tissue fibrosis. Cold Spring Harb. Perspect. Biol. 10:a022293. doi: 10.1101/cshperspect. a022293

Koesters, R., Kaissling, B., Lehir, M., Picard, N., Theilig, F., Gebhardt, R., et al. (2010). Tubular overexpression of transforming growth factor-betal induces autophagy and fibrosis but not mesenchymal transition of renal epithelial cells. Am. J. Pathol. 177, 632-643. doi: 10.2353/ajpath.2010.091012

Kokudo, T., Suzuki, Y., Yoshimatsu, Y., Yamazaki, T., Watabe, T., and Miyazono, K. (2008). Snail is required for TGFbeta-induced endothelial-mesenchymal transition of embryonic stem cell-derived endothelial cells. J. Cell Sci. 121, 3317-3324. doi: 10.1242/jcs.028282

Kopp, J. B., Factor, V. M., Mozes, M., Nagy, P., Sanderson, N., Böttinger, E. P., et al. (1996). Transgenic mice with increased plasma levels of TGF-beta 1 develop progressive renal disease. Lab. Invest. 74, 991-1003.

Korn, T., Bettelli, E., Oukka, M., and Kuchroo, V. K. (2009). IL-17 and Th17 cells. Annu. Rev. Immunol. 27, 485-517. doi: 10.1146/annurev.immunol.021908. 132710

Kulkarni, A. B., Huh, C. G., Becker, D., Geiser, A., Lyght, M., Flanders, K. C., et al. (1993). Transforming growth factor beta 1 null mutation in mice causes excessive inflammatory response and early death. Proc. Natl. Acad. Sci. U.S.A. 90, 770-774. doi: 10.1073/pnas.90.2.770

Lan, H. Y. (2011). Diverse roles of TGF- $\beta /$ Smads in renal fibrosis and inflammation. Int. J. Biol. Sci. 7, 1056-1067. doi: 10.7150/ijbs.7.1056

Lee, H. S. (2011). Pathogenic role of TGF- $\beta$ in the progression of podocyte diseases. Histol. Histopathol. 26, 107-116. doi: 10.14670/hh-26.107

Lee, Y. J., and Han, H. J. (2010). Troglitazone ameliorates high glucose-induced EMT and dysfunction of SGLTs through PI3K/Akt, GSK-3 $\beta$, Snaill, and $\beta$ catenin in renal proximal tubule cells. Am. J. Physiol. Renal Physiol. 298, F1263-F1275. doi: 10.1152/ajprenal.00475.2009

Lewis, E. J., Hunsicker, L. G., Clarke, W. R., Berl, T., Pohl, M. A., Lewis, J. B., et al. (2001). Renoprotective effect of the angiotensin-receptor antagonist irbesartan in patients with nephropathy due to type 2 diabetes. N. Engl. J. Med. 345, 851-860. doi: 10.1056/NEJMoa011303

Li, J., Qu, X., and Bertram, J. F. (2009). Endothelial-myofibroblast transition contributes to the early development of diabetic renal interstitial fibrosis in streptozotocin-induced diabetic mice. Am. J. Pathol. 175, 1380-1388. doi: 10. 2353/ajpath.2009.090096

Li, J., Qu, X., Yao, J., Caruana, G., Ricardo, S. D., Yamamoto, Y., et al. (2010). Blockade of endothelial-mesenchymal transition by a Smad3 inhibitor delays the early development of streptozotocin-induced diabetic nephropathy. Diabetes 59, 2612-2624. doi: 10.2337/db09-1631
Li, J. H., Huang, X. R., Zhu, H. J., Oldfield, M., Cooper, M., Truong, L. D., et al. (2004). Advanced glycation end products activate Smad signaling via TGF-betadependent and independent mechanisms: implications for diabetic renal and vascular disease. FASEB J. 18, 176-178. doi: 10.1096/fj.02-1117fje

Li, Y., Li, H., Liu, S., Pan, P., Su, X., Tan, H., et al. (2018). Pirfenidone ameliorates lipopolysaccharide-induced pulmonary inflammation and fibrosis by blocking NLRP3 inflammasome activation. Mol. Immunol. 99, 134-144. doi: 10.1016/j. molimm.2018.05.003

Lim, A. K. H., Ma, F. Y., Nikolic-Paterson, D. J., Kitching, A. R., Thomas, M. C., and Tesch, G. H. (2010). Lymphocytes promote albuminuria, but not renal dysfunction or histological damage in a mouse model of diabetic renal injury. Diabetologia 53, 1772-1782. doi: 10.1007/s00125-010-1757-1

Liu, F. Y., Li, X. Z., Peng, Y. M., Liu, H., and Liu, Y. H. (2008). Arkadia regulates TGF-beta signaling during renal tubular epithelial to mesenchymal cell transition. Kidney Int. 73, 588-594. doi: 10.1038/sj.ki.5002713

Livingston, M. J., Ding, H. F., Huang, S., Hill, J. A., Yin, X. M., and Dong, Z. (2016). Persistent activation of autophagy in kidney tubular cells promotes renal interstitial fibrosis during unilateral ureteral obstruction. Autophagy 12, 976-998. doi: 10.1080/15548627.2016.1166317

Loeffler, I., Liebisch, M., Allert, S., Kunisch, E., Kinne, R. W., and Wolf, G. (2018). FSP1-specific SMAD2 knockout in renal tubular, endothelial, and interstitial cells reduces fibrosis and epithelial-to-mesenchymal transition in murine STZinduced diabetic nephropathy. Cell Tissue Res. 372, 115-133. doi: 10.1007/ s00441-017-2754-1

Lu, A., Miao, M., Schoeb, T. R., Agarwal, A., and Murphy-Ullrich, J. E. (2011). Blockade of TSP1-dependent TGF- $\beta$ activity reduces renal injury and proteinuria in a murine model of diabetic nephropathy. Am. J. Pathol. 178, 2573-2586. doi: 10.1016/j.ajpath.2011.02.039

Lu, Q., Wang, W. W., Zhang, M. Z., Ma, Z. X., Qiu, X. R., Shen, M., et al. (2019). ROS induces epithelial-mesenchymal transition via the TGFbeta1/PI3K/Akt/mTOR pathway in diabetic nephropathy. Exp. Ther. Med. 17, 835-846. doi: 10.3892/etm.2018.7014

Lv, W., Booz, G. W., Wang, Y., Fan, F., and Roman, R. J. (2018). Inflammation and renal fibrosis: recent developments on key signaling molecules as potential therapeutic targets. Eur. J. Pharmacol. 820, 65-76. doi: 10.1016/j.ejphar.2017. 12.016

Ma, L. J., Jha, S., Ling, H., Pozzi, A., Ledbetter, S., and Fogo, A. B. (2004). Divergent effects of low versus high dose anti-TGF-beta antibody in puromycin aminonucleoside nephropathy in rats. Kidney Int. 65, 106-115. doi: 10.1111/j. 1523-1755.2004.00381.x

Matoba, K., Kawanami, D., Nagai, Y., Takeda, Y., Akamine, T., Ishizawa, S., et al. (2017). Rho-kinase blockade attenuates podocyte apoptosis by inhibiting the notch signaling pathway in diabetic nephropathy. Int. J. Mol. Sci. 18:E1795. doi: $10.3390 /$ ijms 18081795

Meng, X.-M. (2019). Inflammatory mediators and renal fibrosis. Adv. Exp. Med. Biol. 1165, 381-406. doi: 10.1007/978-981-13-8871-2_18

Meng, X. M., Chung, A. C., and Lan, H. Y. (2013). Role of the TGF-beta/BMP7/Smad pathways in renal diseases. Clin. Sci. 124, 243-254. doi: 10.1042/ CS20120252

Meng, X. M., Huang, X. R., Chung, A. C., Qin, W., Shao, X., Igarashi, P., et al. (2010). Smad2 protects against TGF-beta/Smad3-mediated renal fibrosis. J. Am. Soc. Nephrol. 21, 1477-1487. doi: 10.1681/asn.2009121244

Meng, X. M., Huang, X. R., Xiao, J., Chung, A. C., Qin, W., Chen, H. Y., et al. (2012). Disruption of Smad4 impairs TGF- $\beta / S m a d 3$ and Smad7 transcriptional regulation during renal inflammation and fibrosis in vivo and in vitro. Kidney Int. 81, 266-279. doi: 10.1038/ki.2011.327

Miyazawa, K., and Miyazono, K. (2017). Regulation of TGF- $\beta$ family signaling by inhibitory smads. Cold Spring Harb. Perspect. Biol. 9:a022095. doi: 10.1101/ cshperspect.a022095

Morales, M. G., Vazquez, Y., Acuña, M. J., Rivera, J. C., Simon, F., Salas, J. D., et al. (2012). Angiotensin II-induced pro-fibrotic effects require p38MAPK activity and transforming growth factor beta 1 expression in skeletal muscle cells. Int. J. Biochem. Cell Biol. 44, 1993-2002. doi: 10.1016/j.biocel.2012.07.028

Mu, D., Cambier, S., Fjellbirkeland, L., Baron, J. L., Munger, J. S., Kawakatsu, H., et al. (2002). The integrin alpha(v)beta8 mediates epithelial homeostasis through MT1-MMP-dependent activation of TGF-beta1. J. Cell Biol. 157, 493507. doi: $10.1083 /$ jcb. 200109100 
Munger, J. S., Harpel, J. G., Gleizes, P. E., Mazzieri, R., Nunes, I., and Rifkin, D. B. (1997). Latent transforming growth factor-beta: structural features and mechanisms of activation. Kidney Int. 51, 1376-1382. doi: 10.1038/ki. 1997.188

Munger, J. S., Huang, X., Kawakatsu, H., Griffiths, M. J., Dalton, S. L., Wu, J., et al. (1999). The integrin alpha v beta 6 binds and activates latent TGF beta 1: a mechanism for regulating pulmonary inflammation and fibrosis. Cell 96, 319-328. doi: 10.1016/s0092-8674(00)80545-0

Murphy-Ullrich, J. E., and Suto, M. J. (2018). Thrombospondin-1 regulation of latent TGF- $\beta$ activation: a therapeutic target for fibrotic disease. Matrix Biol. 68-69, 28-43. doi: 10.1016/j.matbio.2017.12.009

Najafian, B., Fogo, A. B., Lusco, M. A., and Alpers, C. E. (2015). AJKD atlas of renal pathology: diabetic nephropathy. Am. J. Kidney Dis. 66, e37-e38. doi: 10.1053/j.ajkd.2015.08.010

Nakao, A., Afrakhte, M., Morén, A., Nakayama, T., Christian, J. L., Heuchel, R., et al. (1997a). Identification of Smad7, a TGFbeta-inducible antagonist of TGF-beta signalling. Nature 389, 631-635. doi: 10.1038/39369

Nakao, A., Imamura, T., Souchelnytskyi, S., Kawabata, M., Ishisaki, A., Oeda, E., et al. (1997b). TGF-beta receptor-mediated signalling through Smad2, Smad3, and Smad4. EMBO J. 16, 5353-5362. doi: 10.1093/emboj/16.17. 5353

Panchapakesan, U., Pegg, K., Gross, S., Komala, M. G., Mudaliar, H., Forbes, J., et al. (2013). Effects of SGLT2 inhibition in human kidney proximal tubular cells-renoprotection in diabetic nephropathy? PLoS One 8:e54442. doi: 10.1371/ journal.pone.0054442

Pardali, E., Sanchez-Duffhues, G., Gomez-Puerto, M. C., and Ten Dijke, P. (2017). TGF- $\beta$-induced endothelial-mesenchymal transition in fibrotic diseases. Int. J. Mol. Sci. 18:2157. doi: 10.3390/ijms18102157

Parving, H. H., Lehnert, H., Bröchner-Mortensen, J., Gomis, R., Andersen, S., and Arner, P. (2001). The effect of irbesartan on the development of diabetic nephropathy in patients with type 2 diabetes. N. Engl. J. Med. 345, 870-878. doi: 10.1056/NEJMoa011489

Perkovic, V., Jardine, M. J., Neal, B., Bompoint, S., Heerspink, H. J. L., Charytan, D. M., et al. (2019). Canagliflozin and renal outcomes in type 2 diabetes and nephropathy. N. Engl. J. Med. 380, 2295-2306. doi: 10.1056/NEJMoa1811744

Petersen, M., Thorikay, M., Deckers, M., van Dinther, M., Grygielko, E. T., Gellibert, F., et al. (2008). Oral administration of GW788388, an inhibitor of TGF-beta type I and II receptor kinases, decreases renal fibrosis. Kidney Int. 73, 705-715. doi: 10.1038/sj.ki.5002717

Pourgholamhossein, F., Rasooli, R., Pournamdari, M., Pourgholi, L., SamarehFekri, M., Ghazi-Khansari, M., et al. (2018). Pirfenidone protects against paraquat-induced lung injury and fibrosis in mice by modulation of inflammation, oxidative stress, and gene expression. Food Chem. Toxicol. 112, 39-46. doi: 10.1016/j.fct.2017.12.034

Qi, W., Chen, X., Polhill, T. S., Sumual, S., Twigg, S., Gilbert, R. E., et al. (2006). TGF-betal induces IL- 8 and MCP-1 through a connective tissue growth factorindependent pathway. Am. J. Physiol. Renal Physiol. 290, F703-F709. doi: 10. 1152/ajprenal.00254.2005

RamachandraRao, S. P., Zhu, Y., Ravasi, T., McGowan, T. A., Toh, I., Dunn, S. R. et al. (2009). Pirfenidone is renoprotective in diabetic kidney disease. J. Am. Soc. Nephrol. 20, 1765-1775. doi: 10.1681/asn.2008090931

Sanjabi, S., Zenewicz, L. A., Kamanaka, M., and Flavell, R. A. (2009). Antiinflammatory and pro-inflammatory roles of TGF-beta, IL-10, and IL-22 in immunity and autoimmunity. Curr. Opin. Pharmacol. 9, 447-453. doi: 10.1016/ j.coph.2009.04.008

Sharma, K., Ix, J. H., Mathew, A. V., Cho, M., Pflueger, A., Dunn, S. R., et al. (2011). Pirfenidone for diabetic nephropathy. J. Am. Soc. Nephrol. 22, 1144-1151. doi: 10.1681/asn.2010101049

Sharma, K., Jin, Y., Guo, J., and Ziyadeh, F. N. (1996). Neutralization of TGF-beta by anti-TGF-beta antibody attenuates kidney hypertrophy and the enhanced extracellular matrix gene expression in STZ-induced diabetic mice. Diabetes 45 , 522-530. doi: 10.2337/diab.45.4.522

Sheppard, D. (2004). Roles of alphav integrins in vascular biology and pulmonary pathology. Curr. Opin. Cell Biol. 16, 552-557. doi: 10.1016/j.ceb.2004.06.017

Shihab, F. S., Bennett, W. M., Tanner, A. M., and Andoh, T. F. (1997). Angiotensin II blockade decreases TGF-betal and matrix proteins in cyclosporine nephropathy. Kidney Int. 52, 660-673. doi: 10.1038/ki.1997.380
Shull, M. M., Ormsby, I., Kier, A. B., Pawlowski, S., Diebold, R. J., Yin, M., et al. (1992). Targeted disruption of the mouse transforming growth factorbeta 1 gene results in multifocal inflammatory disease. Nature 359, 693-699. doi: 10.1038/359693a0

Sureshbabu, A., Muhsin, S. A., and Choi, M. E. (2016). TGF-beta signaling in the kidney: profibrotic and protective effects. Am. J. Physiol. Renal Physiol. 310, F596-F606. doi: 10.1152/ajprenal.00365.2015

Sutariya, B., Jhonsa, D., and Saraf, M. N. (2016). TGF- $\beta$ : the connecting link between nephropathy and fibrosis. Immunopharmacol. Immunotoxicol. 38, 39-49. doi: 10.3109/08923973.2015.1127382

Sweetwyne, M. T., Gruenwald, A., Niranjan, T., Nishinakamura, R., Strobl, L. J., and Susztak, K. (2015). Notch1 and Notch2 in podocytes play differential roles during diabetic nephropathy development. Diabetes 64, 4099-4111. doi: 10 . 2337/db15-0260

Ueberham, E., Löw, R., Ueberham, U., Schönig, K., Bujard, H., and Gebhardt, R. (2003). Conditional tetracycline-regulated expression of TGF-betal in liver of transgenic mice leads to reversible intermediary fibrosis. Hepatology 37, 1067-1078. doi: 10.1053/jhep.2003.50196

Voelker, J., Berg, P. H., Sheetz, M., Duffin, K., Shen, T., Moser, B., et al. (2017). Anti-TGF-1 antibody therapy in patients with diabetic nephropathy. J. Am. Soc. Nephrol. 28, 953-962. doi: 10.1681/asn.2015111230

Wang, Y. W., Liou, N. H., Cherng, J. H., Chang, S. J., Ma, K. H., Fu, E., et al. (2014). siRNA-targeting transforming growth factor-beta type I receptor reduces wound scarring and extracellular matrix deposition of scar tissue. J. Invest. Dermatol. 134, 2016-2025. doi: 10.1038/jid.2014.84

Weigert, C., Brodbeck, K., Klopfer, K., Häring, H. U., and Schleicher, E. D. (2002). Angiotensin II induces human TGF-beta 1 promoter activation: similarity to hyperglycaemia. Diabetologia 45, 890-898. doi: 10.1007/s00125-002-0843-4

Wipff, P.-J., and Hinz, B. (2008). Integrins and the activation of latent transforming growth factor betal - an intimate relationship. Eur. J. Cell Biol. 87, 601-615. doi: 10.1016/j.ejcb.2008.01.012

Wong, M. G., Panchapakesan, U., Qi, W., Silva, D. G., Chen, X. M., and Pollock, C. A. (2011). Cation-independent mannose 6-phosphate receptor inhibitor (PXS25) inhibits fibrosis in human proximal tubular cells by inhibiting conversion of latent to active TGF-beta1. Am. J. Physiol. Renal Physiol. 301, F84-F93. doi: 10.1152/ajprenal.00287.2010

Xavier, S., Vasko, R., Matsumoto, K., Zullo, J. A., Chen, R., Maizel, J., et al. (2015). Curtailing endothelial TGF- $\beta$ signaling is sufficient to reduce endothelialmesenchymal transition and fibrosis in CKD. J. Am. Soc. Nephrol. 26, 817-829. doi: 10.1681/ASN.2013101137

Xie, Y., Jiang, H., Zhang, Q., Mehrotra, S., Abel, P. W., Toews, M. L., et al. (2016). Upregulation of RGS2: a new mechanism for pirfenidone amelioration of pulmonary fibrosis. Respir. Res. 17:103. doi: 10.1186/s12931-016-0418-4

Xu, L., Cui, W. H., Zhou, W. C., Li, D. L., Li, L. C., Zhao, P., et al. (2017). Activation of Wnt/beta-catenin signalling is required for TGF-beta/Smad2/3 signalling during myofibroblast proliferation. J. Cell. Mol. Med. 21, 1545-1554. doi: $10.1111 / \mathrm{jcmm} .13085$

Xu, Y., Yang, S., Huang, J., Ruan, S., Zheng, Z., and Lin, J. (2012). Tgf- $\beta 1$ induces autophagy and promotes apoptosis in renal tubular epithelial cells. Int. J. Mol. Med. 29, 781-790. doi: 10.3892/ijmm.2012.911

Yan, X., Liu, Z., and Chen, Y. (2009). Regulation of TGF-beta signaling by Smad7. Acta Biochim. Biophys. Sin. 41, 263-272. doi: 10.1093/abbs/gmp018

Yang, D., Livingston, M. J., Liu, Z., Dong, G., Zhang, M., Chen, J. K., et al. (2018). Autophagy in diabetic kidney disease: regulation, pathological role and therapeutic potential. Cell. Mol. Life Sci. 75, 669-688. doi: 10.1007/s00018-0172639- 1

Zechel, J., Gohil, H., Lust, W. D., and Cohen, A. (2002). Alterations in matrix metalloproteinase-9 levels and tissue inhibitor of matrix metalloproteinases1 expression in a transforming growth factor-beta transgenic model of hydrocephalus. J. Neurosci. Res. 69, 662-668. doi: 10.1002/jnr.10326

Zeisberg, M., Hanai, J., Sugimoto, H., Mammoto, T., Charytan, D., Strutz, F., et al. (2003). BMP-7 counteracts TGF-betal-induced epithelial-to-mesenchymal transition and reverses chronic renal injury. Nat. Med. 9, 964-968. doi: 10.1038/ nm888

Zhang, L., Long, J., Jiang, W., Shi, Y., He, X., Zhou, Z., et al. (2016). Trends in chronic kidney disease in China. N. Engl. J. Med. 375, 905-906. doi: 10.1056/ NEJMc1602469 
Zhang, Y., and Huang, W. (2018). Transforming Growth Factor betal (TGFbeta1)-Stimulated Integrin-Linked Kinase (ILK) Regulates Migration and Epithelial-Mesenchymal Transition (EMT) of Human Lens Epithelial Cells via Nuclear Factor kappaB (NF-kappaB). Med. Sci. Monit. 24, 7424-7430. doi: 10.12659/MSM.910601

Ziyadeh, F. N., Hoffman, B. B., Han, D. C., Iglesias-De La Cruz, M. C., Hong, S. W., Isono, M., et al. (2000). Long-term prevention of renal insufficiency, excess matrix gene expression, and glomerular mesangial matrix expansion by treatment with monoclonal antitransforming growth factor-beta antibody in db/db diabetic mice. Proc. Natl. Acad. Sci. U.S.A. 97, 8015-8020. doi: 10.1073/ pnas. 120055097
Conflict of Interest: The authors declare that the research was conducted in the absence of any commercial or financial relationships that could be construed as a potential conflict of interest.

Copyright (c) 2020 Zhao, Zou and Liu. This is an open-access article distributed under the terms of the Creative Commons Attribution License (CC BY). The use, distribution or reproduction in other forums is permitted, provided the original author(s) and the copyright owner(s) are credited and that the original publication in this journal is cited, in accordance with accepted academic practice. No use, distribution or reproduction is permitted which does not comply with these terms. 